
\title{
$\begin{array}{ll}\text { Research Square } & \text { They should not be considered conclusive, used to inform clinical practice, } \\ \text { or referenced by the media as validated information. }\end{array}$
}

\section{Dietary and exercise interventions for perimenopausal women Health status impact study}

\author{
Shuping Hao \\ pinggu hospital, Capital Medical University Affiliated Beijing Friendship Hospital \\ Sisi Tan \\ Capital Medical University Affiliated Beijing Friendship Hospital \\ Jing Li \\ pinggu hospital, Capital Medical University Affiliated Beijing Friendship Hospital \\ Weimin Li \\ pinggu hospital, Capital Medical University Affiliated Beijing Friendship Hospital \\ Jingyun Li \\ pinggu hospital, Capital Medical University Affiliated Beijing Friendship Hospital \\ Xiaochen Cai \\ pinggu hospital,Capital Medical University Affiliated Beijing Friendship Hospital \\ zhongxin hong ( $\sim$ hongzhongxin2020@163.com) \\ Capital Medical University Affiliated Beijing Friendship Hospital
}

\section{Research article}

Keywords: Perimenopausal period, Body composition, Dietary interventions, Resistance motion

Posted Date: April 8th, 2021

DOI: https://doi.org/10.21203/rs.3.rs-398158/v1

License: (c) (1) This work is licensed under a Creative Commons Attribution 4.0 International License. Read Full License

Version of Record: A version of this preprint was published at Frontiers in Nutrition on January 27th, 2022. See the published version at https://doi.org/10.3389/fnut.2021.752500. 


\section{Abstract}

Background: At present, there are few studies on individualized dietary guidance and exercise intervention for perimenopausal women. The purpose of this article is to explore the effects of centralized health education, health education + individualized diet guidance, and health education + individualized diet guidance + intensive resistance exercise on the physical measurements of perimenopausal women. Design: 78 perimenopausal women divided into three groups: Group A, Group B and Group C. Participants: Group A received routine gynecological diagnosis and treatment and participated in centralized lifestyle health education. Group B required to participate in all intensive education content, professional dietitians to give individualized dietary guidance. Group $\mathrm{C}$ received intensive education, individualized diet intervention, and intensified resistance exercise. Main Measures: Dietary scores, exercise habits, waist circumference, body mass index, fat and muscle mass were observed after 3 months. Results: After intervention, the total diet score of group $C$ was higher than that of group $A$ and $B$, and the red meat score was significantly reduced. The number of patients in group $B$ and group $C$ who exercised $>3$ times per week and the number of resistance exercises per week were significantly increased, while the number of aerobic exercises per week in group $\mathrm{C}$ was significantly increased. Comparison of the changes of body measurement indexes after the three different interventions showed that body fat and waist circumference were significantly reduced, and skeletal muscle weight was significantly increased; body mass index, trunk fat ratio and waist to hip ratio were significantly decreased in group B and C, while trunk muscle was significantly increased in group C. Conclusion: The combined intervention of the three methods can give full play to the synergistic effect of various interventions, and the improvement effect of increasing the appropriate amount of resistance exercise is more obvious, which is worthy of further promotion and application.

Retrospectively registered: researchregistry6331, date of registration : December 4, 2020.

\section{Introduction}

Perimenopausal period refers to the time period from the appearance of signs of ovarian function decline until one year after the last menstruation in woman. It refers to the transitional period from maturity to old age in women. Postmenopausal fat is centripetally distributed and visceral fat increases, leading to increased risk of chronic diseases such as coronary heart disease and diabetes, and comprehensive treatment of diet and exercise for obese menopausal women can significantly improve blood lipid levels, reduce fat percentage, and at the same time improve insulin resistance and reduce plasma insulin levels [1], which helps to reduce medical expenditure and mortality of chronic diseases such as diabetes and hypertension, and help improve the overall health of the population. However, no specific method is given on how to scientifically and effectively guide diet and exercise to adjust body composition [2]. At present, there are few studies on individualized dietary guidance and exercise intervention for perimenopausal women. This study aims to explore the impact of different intervention methods on the diet and exercise behavior and physical health indicators of perimenopausal women in this region. Provide evidence.

\section{Materials And Methods}

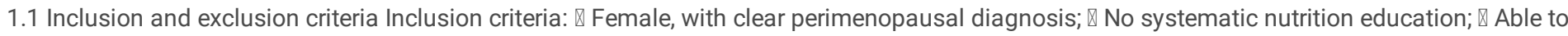
walk without assistance; $₫$ Able to communicate normally. Exclusion criteria: खHaving taken weight-loss drugs for weight loss treatment within 3 months; खHaving suffered from myocardial infarction, unstable cardiovascular disease or other diseases in the past 3 months; $\bigotimes$ Chronic renal

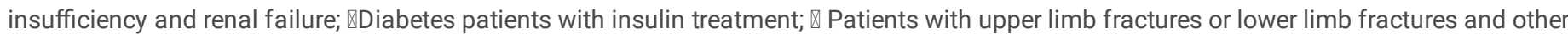
exercise contraindications in the past 3 months; $\mathbb{Q}$ Neuromuscular diseases or taking drugs that affect neuromuscular function.

1.2 Research objects $₫ 78$ perimenopausal women from June 2018 to August 2018 in the gynecology outpatient department of our hospital were recruited as the research objects, with an average age of $48.65 \pm 3.06$ years old. According to the different body mass index, they were divided into two groups: normal weight group and overweight and obese group. At the same time, they were numbered and randomly divided into 3 groups A, B, and C. Group A was the collective education group with 18 cases; Group B was the individualized diet group with 28 cases; Group C was individualized diet + resistance exercise group with 32 cases. This study has been reviewed by the ethics committee of our hospital, and all participants signed an informed consent form.

\subsection{Methods of intervention}

1.3.1 Group intervention: Group A received routine gynecological diagnosis and treatment, and participated in lectures by nutritionists, pharmacists and nurses. They taught about the characteristics of menopausal nutrition and metabolism, the meaning and principles of diet intervention, exercise methods and precautions, drug selection and administration methods. In addition to collective education, Group B followed individualized dietary guidance in accordance with DASH diet principles, recorded a diet diary 3 days a week and uploaded diet diary to WeChat in time, unreasonable diet structure was corrected at any time, and demonstration meals was provided once a month. Group C received collective education and individualized dietary interventions. At the same time, professional sports coaches conducted on-site training and guidance. After 3 months of intervention, the changes in various observation indicators were reviewed.

1.3.2 Diet score: This study was improved on the basis of Shao Jie et al's DASH diet score method[3], and established a diet score based on the classification of 13 main foods. The main guiding principles of the 13 foods are: sufficient fruits, vegetables, low-fat dairy products; moderate 
amounts of nuts and beans, white meats such as poultry, fish and shrimp, whole grain beans and potatoes; reduce fat and animal organs; control the intake of salt, red meat and processed meat, desserts and sweet drinks. For fruits, vegetables, nuts and beans, low-fat dairy products, and whole grains, the lowest intake frequency is given 0 points, the highest is given 4 points, and the middle is given 1 to 3 points. For sweet drinks, red meat, processed meat, fatty meat and animal offal, the lowest intake frequency and salt intake are given 4 points; the highest intake frequency and salt intake are given 0 points, and the middle is given 3 to 1 points respectively. Finally, the total scores of the 13 food categories are added to obtain the diet score.

1.3.3 The exercise mode is guided by the sports coach on-site. Every Monday and Thursday, it concentrates on strengthening resistance exercises, 30-40 minutes each time. The exercise process design: prepare for 5 minutes $\rightarrow$ upper limb dumbbell weight series exercise 15 minutes $\rightarrow$ lower limb squat, squat walking for 15 minutes $\rightarrow$ stretching and finishing for 5 minutes; aerobic exercise for more than 2 days a week, brisk walking or jogging 8000-10000 steps a day, and record exercise frequency.

\subsection{Observation indicators}

1.4.1 General information: It includes name, age, occupation, education, education level, waist circumference, height, production status, menopause status, exercise status, past medical history including hypertension, diabetes and hyperlipidemia, liver and kidney disease, etc., medication status.

1.4.2 For height (m), use a height range finder (Jiangsu Suhong Medical Equipment Co., Ltd., license number, Su made 00000600), remove shoes, and after strict calibration, the result is accurate to $0.1 \mathrm{~cm}$.

1.4.3 Waist circumference $(\mathrm{cm})$ is measured at the midpoint between the ribs and the iliac ridge, using a soft ruler made of non-stretchable material, and the scale must be read to $0.1 \mathrm{~cm}$.

1.4.4 Body composition measurement uses the Inbody770 body composition analyzer (South Korea's Basbes Medical Instruments Trading Co., Ltd.) to conduct body composition detection using the bioelectrical impedance method. Operation method: $₫$ On an empty stomach or fasting 4 hours before the test, stopping strenuous activities, empty excrement and urine, wear less clothes, and not carrying heavy items and accessories.

\Research subjects stand barefoot on the detector, with both heels and forefoot on the foot electrodes; hold the hand electrodes with both hands, the thumb and the other four fingers are in close contact with the electrodes, and enter the name, age, gender, and height, start measurement after coding, measurement time is 2 to 3 minutes, record body mass index, body fat mass, trunk fat ratio, waist-to-hip ratio (WHR), skeletal muscle, trunk muscle mass.

1.4.5 The diagnostic criteria for overweight and obesity uses height and weight to calculate body mass index (BMI) (weight [Kg]/height [ $\left.\mathrm{m}^{2}\right]$ ). And in accordance with WS/T428-2013 Chinese adult weight judgment standard: normal weight (18.5- 23.99kg/ $\left.\mathrm{m}^{2}\right)$, overweight $\left(24-27.99 \mathrm{~kg} / \mathrm{m}^{2}\right)$ and obesity (greater than or equal to $28 \mathrm{~kg} / \mathrm{m}^{2}$ ). According to the "Guidelines for the Prevention and Control of Overweight and Obesity in Chinese Adults" published by the Department of Disease Control of the Health and Family Planning Commission in 2003 , BMl<18.5 kg/ $\mathrm{m}^{2}$ is considered to be too light, and $18.5 \mathrm{~kg} / \mathrm{m}^{2} \leq \mathrm{BMI} \leq 23.9 \mathrm{~kg} / \mathrm{m}^{2}$ is considered normal , $24.0 \leq \mathrm{BMl} \leq 27.9 \mathrm{~kg} / \mathrm{m}^{2}$ is overweight, $\mathrm{BMl} \geq 28.0 \mathrm{~kg} / \mathrm{m}^{2}$ is obesity, and female waist circumference $\geq 80 \mathrm{~cm}$ is the central obesity [4].

1.5 Statistical methods: SPSS17.0 statistical analysis software was used for data processing. All measurement data were expressed as mean \pm standard deviation $\mathbf{E S D}$. ANOVA test was used to compare measurement data between groups, paired t test was used to compare measurement data before and after intervention; Chi-square test was used to compare count data (and classification data), and $P<0.05$ indicated that the difference was statistically significant.

\section{Results And Analysis}

2.1 General information: Before the observation, there was no statistical difference in age, educational background, and occupational data of groups A, B, and C. See Table 1 for $P>0.05$.

2.2 Comparison of dietary scores before and after different intervention methods: Before intervention, there was no difference in food intake scores and total scores of different groups; after the intervention, the scores of the three groups of DASH diet, nuts, soy products, low-fat milk, whole grains, poultry, fish and shrimp white meat, salt, and desserts were significantly improved, and the differences were statistically significant, $P<0.05$; before and after the intervention, there was no statistical difference in the scores of the three groups of fruits and processed meat, $P>0.05$. Compared with before the intervention, after the intervention, vegetables in group $C$, processed meat and sweet drinks in group B and C; the score of red meat in group $A$ was increased, the score of red meat intake in group $C$ was significantly decreased, the score of fat and animal viscera in group $A$ and group $B$ were significantly increased, the difference was statistically significant, $P<0.05$; Compared with group A, the total score of DASH diet and vegetable intake score of group B and C increased significantly, and the low-fat milk intake score of group B increased significantly; the scores of nuts, whole grains and desserts in group $\mathrm{C}$ were significantly improved, the scores of red meat in group $\mathrm{C}$ were significantly reduced, and the frequency of red meat eating increased, the difference was statistically significant, $P<0.05$; after the intervention, the total diet score of group $C$ was higher than that of $A$ and $B$, and the difference was statistically significant, $P<0.05$. See Table 2.

Page $3 / 9$ 
2.3 Comparison of exercise frequency before and after different intervention methods: Before intervention, group $A$, group $B$ and group $C$ exercised irregularly every week, 1-3 times a week, and there was no significant difference in the number of cases where regular exercise was more than 3 times per week, $\square>0.05$; After the intervention, the number of regular exercise $>3$ times a week in group $B$ and $C$ increased significantly, and the difference was statistically significant, $1<0.05$, see Table 3 .

2.4 Comparison of changes in the number of weekly aerobic and resistance exercises before and after the observation of different intervention methods: After the intervention, there was no significant increase in the weekly aerobic exercises in groups A and B, the number of resistance exercises in group A did not change significantly, the number of aerobic exercise per week in group $\mathrm{C}$ was significantly increased, the number of resistance exercises per week in group $B$ and $C$ increased significantly, and the difference was statistically significant, $\angle<0.05$. Comparing the three intervention methods, the weekly aerobic exercises and resistance exercises in group $\mathrm{C}$ increased significantly, higher than those in groups $\mathrm{A}$ and $\mathrm{B}$, and the difference is statistically significant, $\mathbb{Z < 0 . 0 5}$, see Table 4.

2.5 Comparison of waist circumference, body mass index and body composition before and after different intervention methods: After three different intervention methods, body fat and waist circumference were significantly reduced; skeletal muscle weight was significantly increased; BMI, trunk fat ratio, waist-to-hip ratio in groups $\mathrm{B}$ and $\mathrm{C}$ were significantly reduced; the trunk muscles in group $\mathrm{C}$ increased significantly, and the differences were statistically significant, $P<0.05$; Comparing the three intervention methods, there was no statistical difference in waist circumference, BMI, waist-tohip ratio, body fat mass, trunk fat ratio and muscle mass index, $P>0.05$, see Table 5.

\section{Discussion}

Dietary Approaches to Stop Hypertension (DASH), also known as the "DASH diet" model, was proposed in the United States in 1997 as a dietary approach to prevent and control hypertension. It emphasizes the comprehensive effect of the comprehensive diet model on blood pressure [5-6]. Foreign studies have shown that it has a beneficial effect on blood lipids, diabetes, gestational diabetes and cardiovascular disease [7-9]. This study showed that the total score of the DASH diet increased significantly after three different interventions. The frequency of eating nuts, soy products, low-fat milk, whole grains, and white meat of poultry, fish and shrimp was significantly increased, and the intake of salt and the frequency of desserts were significantly reduced; After the intervention of group $\mathrm{C}$, the frequency of eating vegetables increased, and the frequency of eating processed meats and sweet drinks decreased significantly. The difference was statistically significant, $P<0.05$. It shows that different intervention methods can improve the dietary behavior of the population. The dietary behavior of group $\mathrm{C}$ improved more obviously, which may be related to the closer communication and contact with the nutritionist in the intensive resistance exercise group twice a week, which played a role in reminding and urging. This study also showed that the frequency of eating red meat in group $\mathrm{C}$ was significantly higher than that in group $\mathrm{A}$, and the difference was statistically significant, $P<0.05$. It may be related to the emphasis on high-quality protein intake in the nutrition guidance, and local residents prefer to choose lean pork as a source of high-quality protein. It is necessary to strengthen targeted health education, correct past eating habits, appropriately reduce the frequency of eating red meat, and increase the intake of white meat such as chicken, duck, fish, and shrimp.

Studies have shown that both diet and intensive exercise intervention can significantly reduce the incidence of metabolic syndrome. Exercise can increase energy consumption in the body, activate skeletal muscle fatty acid intake system and $\beta$ oxidation pathway, and reduce body fat. Exercise can also increase the uptake and utilization of glucose by skeletal muscle. Exercise can improve lipid metabolism, and can also induce an increase in antioxidant enzyme activity and reduce lipid peroxidation metabolites [10]. Weight is affected by many factors, and the fundamental purpose of weight loss is to reduce fat, so the weight change cannot be used to evaluate the effect of weight loss [11]. Most people know the causes of obesity and the hazards of obesity, and have the desire to control weight. However, the methods of weight control are often limited to eating less and exercising, but they cannot persist. Although some obese patients can implement self-weight loss, most patients need help to obtain effective weight loss techniques [12]. Health education is the basis of obesity intervention. However, due to the above reasons, pure health education intervention has a certain effect on obese patients, but the actual effect is not obvious. Comprehensive intervention measures of health education + nutrition intervention + exercise intervention should be adopted. Practice has proved that this comprehensive intervention is a safe comprehensive intervention method for obese patients [13]. In this study, after the intervention, the number of aerobic exercises and resistance exercises in group A did not increase significantly, the number of aerobic exercises per week in group B did not increase significantly, and the number of aerobic exercises and resistance exercises in group $C$ and the total diet score increased significantly, and the difference was statistically significant, $\square<0.05$, indicating that health education + individualized diet guidance + intensive resistance exercise intervention can better improve diet and exercise habits, which is consistent with the results of Yi Haiwei et al [11,14].

Clinical trial studies have confirmed that adipose tissue is also an endocrine organ, and it is the body's largest endocrine organ. It can release dozens of adipocytokines, such as leptin, resistin, adiponectin, and tumor necrosis factor.They participate in the occurrence and development of obesityrelated diseases by destroying islet 13 cells, inducing hyperinsulinemia, and affecting fat metabolism [15]. High energy, high fat, and high carbohydrate intake may cause body fat accumulation and muscle loss, which is not conducive to the prevention of cardiovascular and cerebrovascular and metabolic diseases. In particular, high energy and high carbohydrate intake should be paid more attention. Low energy intake is not conducive to maintaining muscle mass; high protein intake is not conducive to maintaining minerals; a normal and reasonable ratio of energy intake is most conducive to maintaining standard body composition [16]. Exercise therapy is an important method to prevent and treat obesity, but different exercise methods have different therapeutic effects for patients. Resistance training can improve glucose and fat metabolism. More

Page $4 / 9$ 
importantly, resistance training can increase the body's lean body mass and indirectly improve body fat ratio. Exercise has a positive effect on the prevention and treatment of obesity in postmenopausal women. Medium-intensity aerobic exercise, resistance training or resistance + aerobic exercise are effective ways to lose weight, but the short-term effect is not obvious, and long-term persistence is required [17]. In domestic and foreign studies, dietary exercise intervention can effectively control the body mass, waist circumference, waist-to-hip ratio and body composition of women before and after menopause [18-24]. After the intervention of the three different intervention methods in this study, body fat and waist circumference were significantly reduced; skeletal muscle weight was significantly increased; BMI, trunk fat ratio, waist-to-hip ratio were significantly decreased in groups B and C; trunk muscle increased significantly after intervention in group C, and the difference was statistically significant, $P<0.05$; it indicates that health education + diet guidance + intensive resistance exercise intervention can optimizes the body composition of perimenopausal women.

There are shortcomings in this paper: this study uses different food intake frequency rules to score the DASH diet. Except for the salt score, it does not score specific food intake, and does not record and analyze energy and nutrient intake, which requires to further improve the scoring standards and perfect the design plan; this study records exercise frequency, method and time through WeChat check-in, without introducing information management systems and special equipment to evaluate the compliance and effectiveness of exercise intervention, which may affect the accuracy of the evaluation; the observation period is relatively short and the number of research cases is small. It is necessary to further increase the sample size, extend the observation time, and reduce the research bias.

In summary, although pure health education or health education + dietary intervention can effectively improve diet and exercise habits, reduce waist circumference, body fat, trunk fat, and increase skeletal muscle content, the comprehensive intervention of the three methods can give full play to the synergy of each intervention. Health education + diet guidance + intensive resistance exercise intervention can optimize the body composition of perimenopausal women, which is worthy of further promotion and application.

\section{Declarations}

\section{Ethics approval and consent to participate}

This study was conducted in accordance with the Declaration of Helsinki and approved by the ethics committee of Beijing Pinggu Hospital(2018District Health Division001-01). all participants signed an informed consent form.

\section{Consent to publish}

Not applicable

\section{Availability of data and materials}

The datasets used and/or analysed during the current study are available from the corresponding author on reasonable request.

\section{Competing interests}

The authors declare that they have no competing interests.

\section{Funding}

Scientific research project of Beijing Pinggu District Health Commission, project number: pgwjw2018-09

\section{Authors' contributions}

SP, SS: Designed the study. LJ, WM, JY: Analysed and interpreted the data. XC, ZX: Collected and sorted out of data. Manuscript writing: All authors. Read and approved the final manuscript: All authors

\section{Acknowledgements}

Not applicable

\section{Authors' Information}

Department of Clinical Nutrition, Pinggu Hospital, Beijing Friendship Hospital, affiliated to Capital Medical University

Shuping Hao, Jing Li, Weimin Li, Jingyun Li and Xiaochen Cai

Department of Clinical Nutrition, Beijing Friendship Hospital, Capital Medical University

Sisi Tan and Zhongxin Hong 


\section{References}

[1] Zhu JM. Effect of comprehensive correction of diet and exercise on plasma insulin in obese climacteric women. practical preventive medicine 2013; 20『3®: 368-369.

[2] Baber RJ, Panay N, Fenton A. 2016 IMS Recommendations on women's midlife health and menopause hormone therapy. Climacteric 2016; 19(2): 109-150.

[3] Shao J, Hu YH, Xu FY. Effect of DASH diet on metabolic syndrome in a community in Pudong, Shanghai. Public health and Preventive Medicine 2016; 27(3): 46-49.

[4] Working Group on Obesity in China. Guidelines for preventionand control of over weight and obesity inChinese adults(excerpt). Acta Nutrimenta Sinica 2004; 26(1): 1-4. doi:10.3321/j.issn:0512-7955.2004.01.001.

[5] Saneei P, Salehi-Abargouei A, Esmaillzadeh A, Azadbakht L. Influence of dietary Approaches to Stop Hypertension( DASH) diet on blood pressure: a systematic review and meta analysis on randomized controlled trials. Nutri Meta Cardiovascus dis 2014; 24(12): $1253-1261$.

[6] Zheng C H, Chen C, Li H P. Effects of DASH diet combined with lifestyle change on high normal blood pressure population in community. Taiwan Journal of Preventive Medicine 2013; 19(3): 71-72】

[7] Liese AD, Bortsov A, Gunther AL, Dabelea D, Reynolds K, Standiford D A, et al. Association of DASH diet with cardiovascular risk factors in youth with diabetes mellitus: the SEA囚CH for diabetes in Youth study. Circulation 2011; 123(13): 1410-1417.

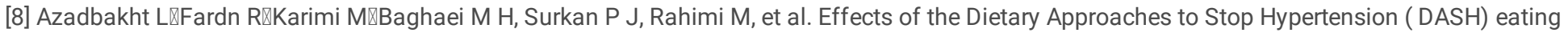
plan on cardiovascular risks among type 2 diabetic patients: a randomized crossover clinical trial. Diabetes Care 2011; 34(1) : 55-57.

[9] Asemi Z, Tabassi Z, Samimi M, Fahiminejad T, Esmaillzadeh A. Favourable effects of the dietary Approaches to Stop Hypertension diet on glucose tolerance and lipid profiles in gestational diabetes: a randomised clinical trial. Br J Nutri 2013; 109(11) : 2024-2030区

[10] Bergstrom A, Pisani P, Tenet V , Wolk A, Adami H O. Overweight as avoidable cause of cancer in Europe. Int J cancer 2001; 91(3): 421-430.

[11] Yi H W, Ma D P, Gao H L, Song Y, Zhan Y J, Li W L. Effect of different intervention methods on weight control of middle-aged obese patients. Preventive medicine in Jiangsu Province 2015; 26(6): 54-55.

[12] Translated by Gao Xiaofang. Interpretation of the US new version of overweight and obesity management guidelines. Zhejiang medicine 2014; 36(2): 101.

[13] Chen SH, Li W, Shen Q. Analysis of the effect of comprehensive intervention on overweight / obese population in community. Chinese Journal of Modern Nursing 2010; 16(17): 2029-2031.

[14] Liu YL, Yuan XY. Effects of diet and exercise on body composition of postmenopausal women and their relationship with related chronic diseases 2017; 52(6): 13-16.

[15] Jia ZT, Tian KH. Analysis of the characteristics and causes of metabolic syndrome in type 1 diabetes mellitus. Chinese Journal of modern medicine 2007; 17: 2770-2772, 2776.

[16] Wan C H, Pan F, Wang H X, Zhu T M. Effect of dietary intake on body composition in perimenopausal women. Maternal and child health care in China 2015;30®36冈: 6522-6524

[17] Yan T. Effect of different exercise methods on body composition of postmenopausal obese women. Journal of Linyi Normal University 2007; 29 छ6冈: 85-88.

[18] Wu LP, Chen R, He C, Ma D, Zhang S J, Zhang Y, et al. Effect of diet and exercise intervention on body composition of perimenopausal women in community. Chinese Journal of nursing 2014; 49(4): 404-409.

[19]Anderson D, Mizzari K, Kain V, Webster J. The effects of a multimodal intervention trial topromote lifestyle factors associatedwith theprevention of cardiovascular disease in menopausalandpostmenopausal Australian women. Health Care WomenInt 2006; 27(3): $238-253$.

[20] Smith-dijulio K, Anderson D. Sustainability of a multimodalintervention topromote lifestyle factors associated with theprevention of cardiovascular disease in midlife Australianwomen『a 5-year follow-up. Health Care Women Int 2009; 30(12): 1111-1130区

[21] Aaedi $P$, Lee MH, Kandiah M, Yassin Z, Shojaeezade D, Hosseini M, et al. Diet intervention to improve cardiovascular risk factors among Iranian postmenopausalwomen. Nutr Res Praet 2010; 4(6): 522-527】 
[22] Kuller L H, Kinzel L S, Pettee K K, Kriska A M, Simkin-Silverman L R, Conroy M B, et a1. Lifestyle interventionandcoronary heart disease risk factor changes over 18 monthsinpostmenopausalwomen: the Women On the Move throughActivity and Nutrition(WOMAN study)clinical trial. JWomens Health(Larchmt) 2006; 15(8): 962-974.

[23] Wildman R P, Schott L L, Brockwell S, Kuller L H, Sutton-Tyrrell K. A dietary and exereise intervention slows menopause-associated progressionof suaclinical atherosclerosis as measureday intimamediathickness of the carotid arteries. J Am Coil Cardiol 2004; 44(3): 579-585.

[24]Kuller L H, SimkinSilverman L R, Wing R R, Meilahn E N , Ives D G . Women'shealthy lifestyle project: a randomized clinical trial: results at54 months. Circulation 2001; 103(1): 32-37.

\section{Tables}

Table 1 Comparison of general data

\begin{tabular}{|c|c|c|c|c|}
\hline Group & Number & $\mathrm{Age} \rrbracket \pm \mathrm{s} \rrbracket$ & $\begin{array}{l}\text { degree } \\
\text { (Below junior college/above bachelor degree ) }\end{array}$ & $\begin{array}{l}\text { Profession } \\
\text { (Medical/non-medical『 }\end{array}$ \\
\hline A & 18 & $49.17 \pm 3.22$ & $9 / 19$ & $4 / 14$ \\
\hline B & 28 & $48.93 \pm 3.04$ & $12 / 16$ & $11 / 17$ \\
\hline $\mathrm{C}$ & 32 & $48.13 \pm 3.00$ & $18 / 14$ & $14 / 18$ \\
\hline$F\left(X^{2}\right)$ & & 0.839 & $1.071^{x}$ & $2.369^{x}$ \\
\hline$P$ & & 0.436 & 0.585 & 0.306 \\
\hline
\end{tabular}

Table 2 Comparison of scores of different diet types in different intervention methods

\begin{tabular}{|c|c|c|c|c|c|c|c|c|c|}
\hline \multirow[t]{2}{*}{ Group } & \multirow[t]{2}{*}{ Number } & \multicolumn{2}{|l|}{ Fruits } & \multicolumn{2}{|l|}{ Vegetables } & \multicolumn{2}{|l|}{ Nuts } & \multicolumn{2}{|c|}{ Soy Products } \\
\hline & & $\begin{array}{l}\text { Before } \\
\text { intervention }\end{array}$ & $\begin{array}{l}\text { After } \\
\text { intervention }\end{array}$ & $\begin{array}{l}\text { Before } \\
\text { intervention }\end{array}$ & $\begin{array}{l}\text { After } \\
\text { intervention }\end{array}$ & $\begin{array}{l}\text { Before } \\
\text { intervention }\end{array}$ & $\begin{array}{l}\text { After } \\
\text { intervention }\end{array}$ & $\begin{array}{l}\text { Before } \\
\text { intervention }\end{array}$ & $\begin{array}{l}\text { After } \\
\text { intervention }\end{array}$ \\
\hline A & 18 & $3.33 \pm 1.029$ & $3.83 \pm 0.707$ & $2.44 \pm 0.705$ & $2.11 \pm 0.471$ & $1.06 \pm 1.162$ & $2.56 \pm 1.338^{*}$ & $1.06 \pm 1.11$ & $\begin{array}{l}2.17 \pm \\
1.098^{*}\end{array}$ \\
\hline B & 28 & $3.57 \pm 0.836$ & $3.68 \pm 0.670$ & $2.43 \pm 0.742$ & $2.57 \pm 0.69 a$ & $1.18 \pm 1.249$ & $2.89 \pm 1.166^{\star}$ & $1.36 \pm 0.951$ & $2.96 \pm 1.036^{*}$ \\
\hline $\mathrm{C}$ & 32 & $3.66 \pm 0.827$ & $3.72 \pm 0.683$ & $2.38 \pm 0.907$ & $2.781 \pm 0.659 a^{*}$ & $1.50 \pm 1.368$ & $2.59 \pm 1.241$ * & $1.53 \pm 1.191$ & $3.03 \pm 0.897 a^{*}$ \\
\hline$F / x^{2}$ & & 1.502 & 1.844 & 0.324 & 11.778 & $0.836 f$ & 1.080 & $2.110 f$ & 8.458 \\
\hline$P$ & & 0.472 & 0.398 & 0.851 & 0.003 & 0.437 & 0.583 & 0.348 & 0.015 \\
\hline
\end{tabular}

\begin{tabular}{|c|c|c|c|c|c|c|c|c|c|}
\hline \multirow[t]{2}{*}{ Group } & \multirow[t]{2}{*}{ Number } & \multicolumn{2}{|l|}{ low-fat milk } & \multicolumn{2}{|l|}{ whole grain } & \multicolumn{2}{|l|}{ white meats } & \multicolumn{2}{|l|}{ salt } \\
\hline & & $\begin{array}{l}\text { Before } \\
\text { intervention }\end{array}$ & $\begin{array}{l}\text { After } \\
\text { intervention }\end{array}$ & $\begin{array}{l}\text { Before } \\
\text { intervention }\end{array}$ & $\begin{array}{l}\text { After } \\
\text { intervention }\end{array}$ & $\begin{array}{l}\text { Before } \\
\text { intervention }\end{array}$ & $\begin{array}{l}\text { After } \\
\text { intervention }\end{array}$ & $\begin{array}{l}\text { Before } \\
\text { intervention }\end{array}$ & $\begin{array}{l}\text { After } \\
\text { intervention }\end{array}$ \\
\hline A & 18 & $0.94 \pm 1.626$ & $2.5 \pm 1.618^{*}$ & $1.33 \pm 1.283$ & $2.11 \pm 1.183^{*}$ & $0.89 \pm 0.676$ & $1.56 \pm 0.922^{*}$ & $2.22 \pm 1.166$ & $\begin{array}{l}2.94 \pm \\
0.802^{*}\end{array}$ \\
\hline B & 28 & $0.54 \pm 1.071$ & $3.14 \pm 1.177^{\mathrm{a}^{*}}$ & $1.39 \pm 0.916$ & $2.71 \pm 0.976^{*}$ & $1.18 \pm 1.092$ & $2.04 \pm 0.962^{*}$ & $1.57 \pm 0.879$ & $2.96 \pm 0.508^{*}$ \\
\hline C & 32 & $0.81 \pm 1.203$ & $3.00 \pm 1.047^{\star}$ & $1.25 \pm 0.950$ & $3.06 \pm 0.840^{a^{*}}$ & $1.25 \pm 1.191$ & $2.00 \pm 0.95^{\star}$ & $1.94 \pm 1.216$ & $3.31 \pm 0.896^{*}$ \\
\hline$F / x^{2}$ & & 1.019 & 1.756 & 0.871 & 8.757 & 0.627 & 4.476 & $2.035^{f}$ & 7.552 \\
\hline$P$ & & 0.601 & 0.416 & 0.647 & 0.013 & 0.731 & 0.107 & 0.139 & 0.023 \\
\hline
\end{tabular}




\begin{tabular}{|c|c|c|c|c|c|c|c|c|c|}
\hline \multirow[t]{2}{*}{ Group } & \multirow[t]{2}{*}{ Number } & \multicolumn{2}{|l|}{ sweet drinks } & \multicolumn{2}{|l|}{ red meat } & \multicolumn{2}{|c|}{ processed meat } & \multicolumn{2}{|c|}{ Fatty meat and offal } \\
\hline & & $\begin{array}{l}\text { Before } \\
\text { intervention }\end{array}$ & $\begin{array}{l}\text { After } \\
\text { intervention }\end{array}$ & $\begin{array}{l}\text { Before } \\
\text { intervention }\end{array}$ & $\begin{array}{l}\text { After } \\
\text { intervention }\end{array}$ & $\begin{array}{l}\text { Before } \\
\text { intervention }\end{array}$ & $\begin{array}{l}\text { After } \\
\text { intervention }\end{array}$ & $\begin{array}{l}\text { Before } \\
\text { intervention }\end{array}$ & $\begin{array}{l}\text { After } \\
\text { intervention }\end{array}$ \\
\hline A & 18 & $3.72 \pm 0.575$ & $3.94 \pm 0.236$ & $1.94 \pm 1.305$ & $2.44 \pm 0.784^{*}$ & $3.83 \pm 0.514$ & $4.0 \pm 0.000$ & $3.56 \pm 0.511$ & $\begin{array}{l}3.94 \pm \\
0.236^{*}\end{array}$ \\
\hline B & 28 & $3.71 \pm 0.535$ & $3.93 \pm 0.262^{*}$ & $2.04 \pm 0.999$ & $2.21 \pm 0.787$ & $3.71 \pm 0.659$ & $4.0 \pm 0.000^{*}$ & $3.64 \pm 0.731$ & $3.93 \pm 0.262^{*}$ \\
\hline C & 32 & $3.59 \pm 0.615$ & $3.68 \pm 0.336^{*}$ & $2.31 \pm 1.091$ & $1.84 \pm 0.920^{\mathrm{a}^{*}}$ & $3.44 \pm 0.982$ & $4.0 \pm 0.000^{*}$ & $3.59 \pm 0.837$ & $3.91 \pm 0.39$ \\
\hline$F / x^{2}$ & & 1.013 & 0.848 & $0.782^{f}$ & 5.015 & 3.628 & - & 1.434 & 0.044 \\
\hline P & & 0.603 & 0.654 & 0.461 & 0.081 & 0.163 & - & 0.488 & 0.978 \\
\hline
\end{tabular}

\begin{tabular}{|llllll|}
\hline Group & Number & dessert & \multicolumn{3}{l|}{ Total score } \\
\cline { 3 - 6 } & & Before intervention & After intervention & Before intervention & After intervention \\
\hline A & 18 & $2.78 \pm 0.943$ & $3.44 \pm 0.705^{*}$ & $29.11 \pm 5.969$ & $37.56 \pm 4.355^{*}$ \\
\hline B & 28 & $3.18 \pm 1.090$ & $3.69 \pm 0.723^{*}$ & $29.5 \pm 5.699$ & $40.71 \pm 3.43^{\mathrm{a}^{*}}$ \\
\hline C & 32 & $2.81 \pm 1.203$ & $3.84 \pm 0.369^{\mathrm{a}^{*}}$ & $29.66 \pm 7.182$ & $40.97 \pm 3.177^{\mathrm{a}^{*}}$ \\
\hline F/X & & 2.954 & 5.560 & $0.166^{f}$ & $5.951^{f}$ \\
\hline P & & 0.228 & 0.062 & 0.847 & 0.004 \\
\hline
\end{tabular}

Table 3 Comparison of motion frequencies before and after intervention

\begin{tabular}{|c|c|c|c|c|c|c|c|}
\hline \multirow[t]{2}{*}{ Group } & \multirow[t]{2}{*}{ Number } & \multicolumn{3}{|c|}{ Before observation } & \multicolumn{3}{|c|}{ After observation } \\
\hline & & $\begin{array}{l}\text { Irregular } \\
\text { exercise }\end{array}$ & $\begin{array}{l}\text { 1-3times/ per } \\
\text { week }\end{array}$ & $\begin{array}{l}>3 \text { times /per } \\
\text { week }\end{array}$ & $\begin{array}{l}\text { Irregular } \\
\text { exercise }\end{array}$ & $\begin{array}{l}\text { 1-3times/ per } \\
\text { week }\end{array}$ & $\begin{array}{l}>3 \text { times/ per } \\
\text { week }\end{array}$ \\
\hline A & 18 & $4 \llbracket 22.2 \rrbracket$ & $4 \otimes 22.2 \rrbracket$ & 10ه55.6囚 & $1 \otimes 5.6 \rrbracket$ & $6 \rrbracket 33.3 \rrbracket$ & 11(61.1) \\
\hline B & 28 & $6 \llbracket 21.4 \rrbracket$ & $9 \llbracket 32.1 \rrbracket$ & $13 \rrbracket 46.4 \rrbracket$ & 1区3.6区 & $6 \rrbracket 21.4 \rrbracket$ & $21 \otimes 75 \rrbracket^{*}$ \\
\hline C & 32 & $3 \otimes 9.4 \rrbracket$ & $13 \varangle 40.6 \rrbracket$ & $16 \otimes 50 \otimes$ & $0 \otimes 0 \rrbracket$ & $4 \otimes 12.5 \rrbracket$ & $28 \llbracket 87.5 \rrbracket^{\star}$ \\
\hline total & 78 & 13囚16.7区 & $26 \rrbracket 33.3 \rrbracket$ & $37 \varangle 47.4 \rrbracket$ & $2 \varangle 2.6 \rrbracket$ & $16 \varangle 20.5 \rrbracket$ & $60876.9 \rrbracket$ \\
\hline$x^{2}$ & & 2.082 & 1.783 & 0.160 & 1.941 & 3.089 & 5.742 \\
\hline P & & 0.353 & 0.410 & 0.923 & 0.510 & 0.213 & 0.057 \\
\hline
\end{tabular}

Note: Compared with before treatment,P * $<0.05$

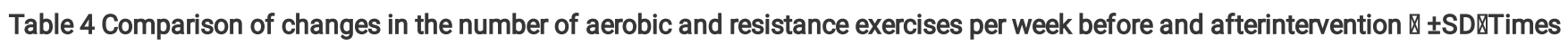

\begin{tabular}{|llllll|}
\hline Group & Number & \multicolumn{2}{l|}{ aerobic exercises times/week } & \multicolumn{2}{c|}{ Resistance exercise times/week } \\
\cline { 3 - 6 } & & Before intervention & After intervention & Before intervention & After intervention \\
\hline A & 18 & $3.61 \pm 3.20$ & $3.89 \pm 3.18$ & $0.44 \pm 1.25$ & $1.28 \pm 2.19$ \\
\hline B & 28 & $3.07 \pm 2.79$ & $3.50 \pm 2.46$ & $0.00 \pm 0.000$ & $1.21 \pm 1.75^{\star}$ \\
\hline C & 32 & $3.72 \pm 2.54$ & $5.66 \pm 3.03 c^{*}$ & $0.19 \pm 0.535$ & $2.72 \pm 1.40 c^{*}$ \\
\hline
\end{tabular}

Note: $f$ is the value of $F$; compared with before treatment, $P *<0.05$; compared with groups $A$ and $B, P c<0.05$

Table5 waist circumference, body mass index and body composition before and after intervention 


\begin{tabular}{|c|c|c|c|c|c|c|c|}
\hline \multirow[t]{2}{*}{ Group } & \multirow[t]{2}{*}{ Number } & \multicolumn{2}{|c|}{ waist circumference $\mathbb{c m} \rrbracket$} & \multicolumn{2}{|l|}{$\mathrm{BMI}\left(\mathrm{kg} / \mathrm{m}^{2}\right)$} & \multicolumn{2}{|c|}{ waist-to-hip ratio } \\
\hline & & $\begin{array}{l}\text { Before } \\
\text { intervention }\end{array}$ & $\begin{array}{l}\text { After } \\
\text { intervention }\end{array}$ & $\begin{array}{l}\text { Before } \\
\text { intervention }\end{array}$ & $\begin{array}{l}\text { After } \\
\text { intervention }\end{array}$ & $\begin{array}{l}\text { Before } \\
\text { intervention }\end{array}$ & After intervention \\
\hline A & 18 & $83.89 \pm 9.46$ & $79.08 \pm 9.64^{*}$ & $25.13 \pm 3.18$ & $25.04 \pm 3.28$ & $0.91 \pm 0.06$ & $0.91 \pm 0.06$ \\
\hline B & 28 & $83.54 \pm 9.49$ & $78.02 \pm 8.01^{*}$ & $25.28 \pm 3.61$ & $24.74 \pm 3.48^{*}$ & $0.91 \pm 0.05$ & $0.90 \pm 0.05^{\star}$ \\
\hline C & 32 & $80.83 \pm 7.59$ & $75.95 \pm 7.72^{\star}$ & $24.45 \pm 3.17$ & $24.09 \pm 2.96^{*}$ & $0.89 \pm 0.39$ & $0.85 \pm 0.37^{\star}$ \\
\hline $\mathrm{F}$ & & 1.010 & 0.935 & 0.516 & 0.577 & 1.988 & 1.905 \\
\hline$P$ & & 0.369 & 0.397 & 0.599 & 0.564 & 0.144 & 0.156 \\
\hline
\end{tabular}

\begin{tabular}{|c|c|c|c|c|c|c|c|c|c|}
\hline \multirow[t]{2}{*}{ Group } & \multirow[t]{2}{*}{ Number } & \multicolumn{2}{|l|}{ body fat $₫ \mathrm{~kg} \rrbracket$} & \multicolumn{2}{|c|}{ Trunk fat ratio $₫ \% \bigotimes$} & \multicolumn{2}{|c|}{ skeletal muscle $\varangle \mathrm{kg} \rrbracket$} & \multicolumn{2}{|c|}{ trunk muscles $₫ \mathrm{~kg} \rrbracket$} \\
\hline & & $\begin{array}{l}\text { Before } \\
\text { intervention }\end{array}$ & $\begin{array}{l}\text { After } \\
\text { intervention }\end{array}$ & $\begin{array}{l}\text { Before } \\
\text { intervention }\end{array}$ & $\begin{array}{l}\text { After } \\
\text { intervention }\end{array}$ & $\begin{array}{l}\text { Before } \\
\text { intervention }\end{array}$ & $\begin{array}{l}\text { After } \\
\text { intervention }\end{array}$ & $\begin{array}{l}\text { Before } \\
\text { intervention }\end{array}$ & $\begin{array}{l}\text { After } \\
\text { intervention }\end{array}$ \\
\hline$A$ & 18 & $23.35 \pm 5.33$ & $22.72 \pm 5.55^{*}$ & $228.03 \pm 56.00$ & $222.75 \pm 58.17$ & $22.04 \pm 2.52$ & $22.34 \pm 2.73^{*}$ & $18.62 \pm 2.19$ & $\begin{array}{l}18.79 \pm \\
2.24\end{array}$ \\
\hline B & 28 & $23.15 \pm 6.13$ & $21.03 \pm 6.18^{*}$ & $227.88 \pm 63.24$ & $210.27 \pm 63.35^{\star}$ & $22.18 \pm 3.20$ & $22.41 \pm 3.02^{*}$ & $18.89 \pm 2.64$ & $18.94 \pm 2.45$ \\
\hline C & 32 & $21.00 \pm 4.75$ & $19.65 \pm 4.48^{\star}$ & $211.49 \pm 54.06$ & $190.91 \pm 58.02^{*}$ & $21.34 \pm 2.38$ & $21.66 \pm 2.29^{\star}$ & $18.03 \pm 1.92$ & $18.17 \pm 1.85^{\star}$ \\
\hline $\mathrm{F}$ & & 1.618 & 1.897 & 0.760 & 1.182 & 0.801 & 0.704 & 1.135 & 1.049 \\
\hline$P$ & & 0.205 & 0.157 & 0.471 & 0.312 & 0.453 & 0.498 & 0.327 & 0.355 \\
\hline
\end{tabular}

Note: Compared with before treatment, $P^{*}<0.05$ 